\title{
A klimatikus jellemző́k hatásai az útpályaszerkezetre
}

\section{Gribovszki Zoltán ${ }^{1}$, Kalicz Péter ${ }^{1}$, Herceg András ${ }^{1}$, Primusz Péter ${ }^{1}$}

\author{
${ }^{1}$ Soproni Egyetem, Erdőmérnöki Kar a Geomatikai, Erdőfeltárási és \\ Vízgazdálkodási Intézet \\ E-mail: zgribo@gmail.com; kaliczp@gmail.com; herceg.andras@uni-sopron.hu; \\ primusz.peter@uni-sopron.hu
}

DOI: $10.36246 /$ UL.2020.1.01

\section{KIVONAT}

A környezeti jellemzők (elsősorban a hömérséklet, a csapadék, a légnedvesség, a fagyás-olvadás ciklusok és a talajvíz mélysége) jelentős hatást gyakorolnak az útburkolatok állapotára és élettartamára tehát a pályaszerkezetek méretezésénél is fontos tényezőként vehetők figyelembe.

Az aszfaltburkolatú pályaszerkezetek tartósságának számításánál, az egyszerüen meghatározható és általában könnyen elérhető meteorológiai paraméterek közül, a hőmérséklet, ennek ingadozása és a csapadék a figyelembe vehető. Bár a hőmérséklettől függő aszfalt merevségi modulust a tényleges, reálisan várható aszfalthőmérséklet alapján célszerü felvenni. Viszont ezen mérések csak korlátozott számban állnak rendelkezésre, a léghőmérséklet mérések viszont igen jól lefedik az országot ezért felhasználhatóak az aszfalthőmérsékletek becslésére (elsősorban szezonálisan, havi gyakorisággal).

Jelen cikk a léghömérséklet és a csapadék általános változási tendenciáit mutatja be és hasonlítja össze Magyarországon három vizsgálati időszakra: 1951-1980; 1981-2010; 2016-2045.

Kulcsszavak: alacsony pályaszerkezet méretezés, klímaváltozás, klimatikus jellemzők, hőmérséklet, csapadék

\section{ABSTRACT}

Environmental parameters (primarily temperature, precipitation, air humidity, freeze-thaw cycles and groundwater depth) have a significant impact on the condition and lifespan of pavements, therefore they can be taken into account as critical factors during pavement design methods.

In calculating the durability of asphalt pavements, temperature, fluctuations of temperature, and precipitation can be taken into account, which are generally available meteorological parameters. Although the temperaturedependent asphalt stiffness modulus should be determined based on the actual, realistic expected asphalt temperature. However, these measurements are only available in a limited number, instead of air temperature measurements that cover the country very well and nevertheless can be used to estimate asphalt temperatures (mainly seasonally, on a monthly basis).

This paper presents and compares general trends of changes in air temperature and precipitation in Hungary for three investigational periods: 1951-1980; 1981-2010; 2016-2045.

Keywords: pavement design, climate change, climatic parameters, temperature, precipitation

\section{Prof. Dr. Gribovszki Zoltán}

A Soproni Egyetem (SOE) Erdömérnöki Karán a Geomatikai, Erdőfeltárási és Vizgazdálkodási Intézet munkatársa. Fö kutatási területe az öko-hidrológia, evapotranszspiráció számitása a talajnedvesség, a talajviz és a lefolyás nagy gyakoriságú mérése alapján. 


\begin{abstract}
Dr. Kalicz Péter
A Soproni Egyetem (SOE) Erdömérnöki Karán a Geomatikai, Erdőfeltárási és Vizgazdálkodási Intézet munkatársa. Fö kutatási területe a hidrológiai modellezés, intercepció automatizálása.
\end{abstract}

Dr. Herceg András

A Soproni Egyetem (SOE) Erdömérnöki Karán a Geomatikai, Erdôfeltárási és Vízgazdálkodási Intézet munkatársa. Fö kutatási területe a vízmérleg-modellezés.

\title{
Dr. Primusz Péter
}

A Soproni Egyetem (SOE) Erdömérnöki Karán a Geomatikai, Erdöfeltárási és Vizgazdálkodási Intézet munkatársa. Fö kutatási területe az útfenntartás és az útpályaszerkezetek méretezése, megerösitése.

\section{BeVEzetés}

A környezeti jellemzők jelentős hatást gyakorolnak az útburkolatokra így a pályaszerkezetek méretezésénél is fontos tényezőként vehetők figyelembe. A környezeti jellemzők közül a hőmérséklet, a csapadék, a légnedvesség, a fagyás-olvadás ciklusok és a talajvíz mélysége befolyásolják leginkább az útburkolatok állapotát és élettartamát. Különösen fontos a környezeti jellemzők alaposabb vizsgálata az alsóbbrendủ vagy mezőgazdasági utaknál, illetve az erdők feltáróhálózatánál valamint az agroerdészeti rendszerek kiszolgáló útjainál. Ezeknél az úthálózatoknál az időjárásnak való kitettség a vékonyabb pályaszerkezet miatt erőteljesebben is érezteti hatását.

Minden klimatikus jellemző szezonális változékonysággal bír, tehát célszerủ a pályaszerkezet méretezését is ezekhez a szezonális változásokhoz kapcsolni (Gupta, 2014). A hajlékony pályaszerkezetek méretezésénél három fö környezeti jellemző változását célszerü figyelembe venni:

- Az aszfalt rétegek hőmérsékletének változásai. Ez a paraméter azért lényeges, mert az aszfaltkeverékek modulusai nagyon érzékenyek a hőmérsékletváltozásra. A burkolatfelszín és a mélyebb rétegek hőmérséklete különbözö termodinamikai, fizikai és meteorológiai folyamatok eredménye. Ezen folyamatok ismerete és vizsgálatokon alapuló megértése nagyon fontos ahhoz, hogy információkat nyerjünk pályaszerkezetünk hőmérséklet viselkedéséről (Ureczky \& Tóth, 2008).

- Az alsó rétegek (elsősorban a földmü) talajnedvességének változásai. A földmü moduluszok általában az optimális talajnedvességre és sürüségre (tömörségre) vonatkoznak. Sok esetben viszont az optimálistól eltérö jellemzőkre korrekciós faktorok szükségesek.

- A fagyás olvadás jelensége és ennek ciklusai igen jelentősen befolyásolják az alsó rétegek és a földmü teherbírását. Hiszen a fagyos periódusok alatt a földmű teherbírása nő, míg az olvadási periódusok alatt jelentősen csökken, tehát a fagyás mélységének és az egyes olvadási ciklusok egymásra következésének ismerete is egy fontos kérdés.

Az elöbbiek szerint tehát az aszfaltburkolatú pályaszerkezetek tartósságának számításánál, az egyszerüen meghatározható és általában könnyen elérhető meteorológiai paraméterek közül, a hőmérséklet, ennek ingadozása és a csapadék a figyelembe vehető tényezők (Boromissza, 1997). Jelen cikk e két paraméter általános változási tendenciáit mutatja be Magyarországon.

\section{A HÖMÉRSÉKLET ÉS CSAPADÉK}

$\mathrm{Az}$ aszfaltkeverékek terheléssel szembeni ellenállása tehát hőmérsékletfüggő. Jelenleg három jellegzetes hőmérséklet tartományhoz rendelik a tönkremeneteli formákat (Pethö, 2008):

- alacsony hőmérsékleti tartomány ( $<0$ Celsius), repedésképződés az aszfaltburkolatban;

- közepes hőmérsékleti tartomány (5-15 Celsius), az aszfaltkeverékek fáradása; 
- magas hőmérsékleti tartomány ( $>30$ Celsius), plasztikus deformációs hajlam (keréknyomképződés).

A valós környezeti változásoknak kitett és igénybevétellel terhelt pályaszerkezeteken az előbbiekben felsorolt tönkremeneteli formák együttesen, illetve egymásra hatást gyakorolva jelennek meg (Pethő, 2008).

A magas hőmérséklet hatása a következő. A sötét felszínủ aszfaltburkolat, a kisebb albedója miatt, a hőmérsékletet általában akkumulálja. A léghőmérséklet és a burkolat hőmérséklet általában nem azonos. A burkolat hőmérséklete általában magasabb, sőt tartósan magasabb. A hőmérséklettől függő aszfalt merevségi modulus tehát nem a léghőmérséklet, hanem a tényleges, reálisan várható aszfalthőmérséklet alapján célszerü felvenni (Boromissza, 1997). Mivel azonban az aszfalthőmérsékletek mérések csak korlátozott számban állnak rendelkezésre, a léghőmérséklet mérések viszont igen jól lefedik az országot ezért felhasználhatóak az aszfalthőmérsékletek becslésére. A léghőmérséklet, mint egyetlen paraméter azonban inkább szezonálisan, havi gyakorisággal használható az aszfalt pályaszerkezetek hőmérsékletének becslésére. A pillanatnyi aszfalthőmérséklet ugyanis nemcsak a léghőmérséklettől, hanem az ezt megelőző időszak (órák, sőt napok) időjárástól is függ. Ezért nehéz nagy időbeli felbontásban általános érvényü összefüggést adni.

A hőmérsékletfüggő aszfaltmodulusz befolyásolja a talajra jutó feszültséget, tehát közvetve az egész pályaszerkezet teherbírását is. Érdemes kiemelni, hogy az összefüggés exponenciális, így a magasabb hőmérsékleti kategóriákban a hatás hatványozott (Pethő, 2008). Hazai viszonyok között az 50 Celsius fokos aszfalthőmérsékletek sem ritkák (Boromissza 1997), amelyek mellett a modulus értéke igen jelentősen megváltozik. A hatás egyébiránt a klímaváltozás kapcsán még jelentősebb lehet.

Az alacsony hőmérsékletek esetén a pályaszerkezet méretezést jelentősen befolyásolja a talajfagy mélysége és tartóssága. Az aszfaltburkolat tartósságára pedig a fagyás-olvadás ciklusok száma és a napi hőmérsékletingadozás gyakorol jelentősebb hatást.

A csapadék mennyisége főkként az elnedvesedésén keresztül elsősorban a talaj teherbírását befolyásolja. Mivel a vegetációs időszakban a párolgás igen jelentős mértékű (általában meghaladja a csapadékot), ezért az éves csapadékmennyiség mellett a téli félév csapadékát is célszerü meghatározni. A magyar pályaszerkezet méretezési utasítás a $600 \mathrm{~mm}$ feletti átlagos csapadékú vidékeket „kedvezőtlennek” minősíti, és ezt a teherbírásnál is figyelembe veszi.

\section{A KLÍMAVÁLtOZÁs UtAKRA VALÓ LEHETSÉGES hatÁSAI}

Az éghajlatváltozás sajátos jellemzője, hogy a megváltozó környezeti feltételek visszahatnak a klímaváltozást elsősorban indukáló társadalmi gazdasági tevékenységre. A következmények megjelenhetnek útjaink állapotában is. Különösen lényeges a kérdés az alsóbbrendü vagy mezőgazdasági, ill. erdészeti utak esetében, amelyek a környezeti jellemzőkre, különösen a földmü nedvességtartalmával kapcsolatos változásokra érzékenyebbek.

Fontos kérdés, hogy infrastruktúránk éghajlati szempontból mennyire időálló. A jelenben zajló tervezések szempontjából pedig meghatározó kérdés, hogy a tervek során kivitelezett utak pályaszerkezetei mennyire állják ki majd a változó klíma hatásait. Ezt a kérdést alapvetőn meghatározza, hogy a tervezés során figyelembe vett tervezési paraméterek (egyenletek állandói, zónahatárok, zónákra jellemző faktorok) mennyire aktuálisak, és mennyire tekintenek esetleg előre az elkövetkező időszak jellemzőit is figyelembe véve. Az előrejelzések szerint ugyanis a klimatikus jellemzők változása valószínüleg a szélsőséges időjárási események gyakoriságának növekedése (Bartholy et al., 2011). A legfontosabb befolyásoló események példaként a hőhullámok, a korai és a kései fagyok, a jelentős szélviharok, a nagy intenzitású felhőszakadásszerủ esőzések és ennek vízelvezetési problémái, valamint a nyári időszakokban fellépő hosszabb aszályos időszakok megjelenése (Bartholy et al., 2011).

Az utakra való hatásokat elemezve néhány példát érdemes kiemelni:

- A rövid idő alatt lehulló, nagy intenzitású csapadékok alámoshatják a közúti töltéseket, partfalakat (Bartholy et al., 2011). Az útpályaszerkezetek gyors tönkremenetelét okozhatja, 
ha azok az „alulról jövő víz” (talajvíz, belvíz vagy árvíz) hatása alá kerülnek. Kiemelten problémás a helyzet akkor, ha a földmüvet nem szemcsés talajból (pl. homok) építették (Gáspár, 2007). Óriási jelentőségü tehát az utak megfelelő vízelevezetési rendszere.

- A tartós aszály a kedvezőtlenebb talajadottságú területeken okozhat állékonyságromlást (földmü/részü összerepedezése).

- Az aszályos időszakok kedvezőtlenül érinthetik az utakat, autópályákat szegélyező növényállományok vitalitását, csökkentve ezáltal a növények szélsőségeket mérséklő hatását. Így a kedvezőtlen hatások még erőteljesebben megjelenhetnek a pályaszerkezetekben (Bartholy et al., 2011).

- Az egyre forrósodó nyári hónapokban fokozott aszfaltkárosodásra számíthatunk. A gyakrabban megjelenő hőségnapok, hőségperiódusok a burkolat nyomvályúsodásának erősödéséhez vezethetnek. Ez a hatás különösen fokozott lehet, ha a napi átlaghőmérséklet legalább három napon keresztül nem süllyed 26 Celsius fok alá (Bartholy et al., 2011).

- A fagypont körüli hőmérséklet és a gyakrabban változó halmazállapotú csapadék is kedvezőtlenül befolyásolhatja az útburkolatok állagát. A fagy hatására megnyíló repedéseken keresztül az aszfaltrepedésekbe szivárgó víz a kátyúsodás erősödéshez vezethet, hiszen a fagypont alatti és fölötti hőmérsékletek gyorsabban váltogatják majd egymást (Bartholy et al., 2011).

- A gyakoribbá váló fagyás felengedés ciklusok a kritikus időszakokban a földmü fokozottabb elnedvesedéséhez így teherbírás csökkenéséhez vezethetnek (Gáspár, 2007).

- A városokban az aszfaltozott utak, a városok ritkásabb növényzete, az egyre sokasodó nagy üvegfelületekkel rendelkező épületek, és az ezek hütését szolgáló légkondicionálók használata erősíti majd a klímaváltozás indukálta hőmérsékletemelkedést (Pongrácz et al., 2006). Ez a hatás tehát a városi területeken a még fokozottabb nyomvályúsodáshoz vezethet.

Az előbbieket összefoglalva megállapítható, hogy a klímaváltozás a megváltozó környezeti jellemzők miatt a pályaszerkezetek tervezési paramétereinek, esetleg magának a tervezési elveknek a módosítását indukálja.

\section{KLIMATIKUS JeLLEMZÖK ÉS VÁLTOZÁSUK}

\subsection{MúltBELI TENDENCIÁK AZ ÉGHAJLATBAN}

\subsubsection{A HÖMÉRSÉKLET ÉS CSAPADÉK ÁTLAGOK ÁLTALÁNOS TENDENCIÁl}

A müszeres mérések kezdet óta az elmúlt 30 évben mutatta Magyarország éghajlata a legintenzívebb változást.

Az évszakok közül a nyarak átlaghőmérséklete emelkedett a leginkább, mértéke az utóbbi 30 évben elérte a 2 Celsius fokot (Bartholy et al., 2011; Lakatos et al., 2012). A nyári melegedési tendenciára azért is érdemes figyelni, mivel az aszfaltkeverékek merevségi modulusai, különösen a plasztikus deformációra való hajlam is erősen változik kedvezőtlen irányba a hőmérséklet emelkedésével. A kapcsolat pl. exponenciális függvénnyel jól leírható (Pethő, 2008), így a változás mértéke a hőmérséklet emelkedésével rohamossá válik.

A csapadék hazánkban, térben és időben egyaránt változékony paraméter, ezért a csapadékváltozások, nem követnek olyan egyértelmü trendet, mint pl. a hömérsékletemelkedés (Bartolly et al., 2011; Lakatos et al., 2012). Az éves csapadékösszeg a XX. század elejétől országos mértékben enyhén csökkent. A csökkenés mértéke a Dunántúlon az országos átlagnál nagyobb mértékü volt (Gálos és Vig, 2014; Bartolly et al., 2011). A csapadékosság a pályaszerkezet méretezés szempontjából elsősorban a pályaszerkezet alatti talaj teherbírását befolyásolhatja. Itt is inkább a nagycsapadékok, valamint a téli csapadékösszeg kiemelt jelentőségére érdemes a figyelmet felhívni. 


\subsubsection{A CSAPADÉK ÉS A HÖMÉRSÉKLET SZÉLSÖSÉGEINEK TENDENCIÁI}

Az elmúlt 30 évben gyakoribbá váltak a szélsőségesen meleg időjárási helyzetek (Gálos et al., 2007; Lakatos et al., 2012). Példaként a nyári napok száma (napi maximum $>25$ Celsius fok) átalagosan 8 nappal, a hőhullámos napok száma (napi átlag $>25$ Celsius fok) 5 nappal nőtt. A fagyos napok száma (napi minimum hömérséklet $<0$ Celsius fok) az általános melegedésnek megfelelően viszont 10 nappal csökkent (Lakatos et al., 2012).

A csapadék időbeli eloszlása is megváltozott az elmúlt néhány évtizedben. A csapadékos napok száma csökkent, így az aszályos nyarak megjelenése gyakoribbá vált (Szalai \& Mika, 2007). A nyári csapadékintenzitás átlagosan növekedett az országban, de térben osztva a problémát már nem ilyen egyértelmű a helyzet. A nyári csapadékintenzitás növekedése a legerőteljesebb Komárom-Esztergom és Pest megyében, a Délnyugat-Dunántúlon viszont a csapadékintenzitás csökkenése figyelhető meg (Lakatos et al., 2012).

\subsection{JÖVÖBELI ÉGHAJLATI TENDENCIÁK}

\subsubsection{HÖMÉRSÉKLET ÉS CSAPADÉK ÁTALAGINAK JÖVÖBELI PROGNÓZISA}

A regionális klíma-előrejelzések alapján az egész európai kontinens területén, minden évszakban felmelegedés várható, amelynek mértéke a 21. század vége felé fokozódik (Christensen et al., 2007, van der Linden et al., 2009; Jacob et al., 2008; Jacob et al., 2013). A melegedés mértéke $2-5{ }^{\circ} \mathrm{C}$ az alkalmazott klímamodell és emissziós forgatókönyvtől függően.

Vautard et al. (2014) kutatásai alapján a globális $2{ }^{\circ} \mathrm{C}$-os átlagnál nagyobb melegedés várható Európában az 1971-2000-es referencia-időszakkal összevetve. A változások Európa szerte eltérőek, ami konkrétan a globálisnál enyhébb melegedést jelent a nyugati régiók, de intenzívebbet Dél-Európára nyáron, illetve Észak- és Kelet-Európára télen. A kutatás 30 éves periódust ölel fel, az SRES globális klímamodell A1B klíma forgatókönyvét alapul véve, $25 \mathrm{~km}$-es felbontásra leskálázva.

$\mathrm{Az}$ éves csapadékösszegek tekintetében Európában 21. század második felére az északi régiók valószínűsíthetően nedvesebbek, míg a déli térségek szárazabbak lesznek (Kjellström et al., 2011). Ezt, a már korábban is előrevetített trendet erősíti meg az IPCC 2014-es jelentése is (IPPC, 2014), finomabb felbontású modellek eredményei alapján (Jacob et al., 2014; Vautard et al., 2013).

Magyarországon a jelen század végére akár 3-4 Celsius fokkal magasabbak is lehetnek a hőmérsékletek, az évszakok közül pedig a nyarak hőmérséklete emelkedhet a leginkább (Bartolly et al., 2011).

A csapadékösszeg tekintetében hazánkra vonatkoztatva nem szignifikáns a jövőbeli változás, mivel úgynevezett átmeneti zónában helyezkedik el. Az évszakok közül viszont nyáron minden klímamodell eredménye szerint a csapadékmennyiség jelentősebb csökkenése várható a század végére, míg ugyanakkor a telek csapadékosabbá válhatnak (Szépszó, 2008; Gálos et al., 2014). Hazánkra a szabálytalan csapadékeloszlás jellemző, így ugyanolyan valószínűséggel jelentkezhetnek heves csapadékesemények, mint erős szárazság (Gálos et al., 2015; Nováky \& Bálint, 2013).

\subsubsection{A HÖMÉRSÉKLET ÉS A CSAPADÉK SZÉLSŐSÉGEINEK JÖVŐBELI PROGNÓZISA}

A jövőben, Európában megnövekedhet az előfordulása a szélsőséges napi maximum hőmérsékleteknek, a szélsőséges napi csapadékoknak és az evvel kapcsolatos árvizeknek. A hőmérséklet és a csapadékintenzitás növekedés magával vonja a hidrológiai ciklus általános felgyorsulását is (Kjellström et al., 2011). Európa egész területén gyakoribbá válhatnak a hőhullámok, ez a hatás a mediterrán területeken még fokozottabb lesz (IPPC, 2014).

Magyarországon a napi maximum és minimumhőmérsékletek tekintetében egyaránt növekedés várható a XXI. század során. Az előrejelzések szerint gyakoribbá válnak majd a meleg hőmérsékleti szélsőségek (hőség és forró napok), azonban a hideg szélsőségek (téli és fagyos napok) száma csökken (Szépszó, 2008). 
A csapadék időbeli eloszlása is átalakul majd a prognózisok szerint. A század végére a csapadékos napok száma tovább csökken a jelenhez képest is. A nagycsapadékok $(20 \mathrm{~mm}<)$ elöfordulása általában (a nyár kivételével) növekedni látszik (Lakatos et al., 2012). A nagycsapadékok következtében előforduló villámárvizek gyakoribbá válhatnak. A hosszabb csapadékmentes periódusok viszont szélsőségesebb aszályokat indukálnak majd (Gálos et al., 2007).

\subsection{A KLIMATIKUS JELLEMZÖK JELENBELI (1981-2010) ALAKULÁSA MAGYARORSZÁG TERÜLETÉN}

Magyarországon az éghajlati elemek szempontjából nagyjából egységes éghajlati körzetekre osztható. A felosztást, az éghajlati paraméterek elemzésé, az egyes közigazgatási régiókhoz célszerü kötni, hiszen a támogatások is valószínúleg régiókhoz köthetők majd. Az egyes régiók a következők: Dunántúl, Közép-Dunántúl, Közép-Magyarország, Észak-Alföld, Dél- Alföld, Nyugat-Dunántúl, Észak-Magyarország. Mindemellett az egyes közigazgatási régiók elhelyezkedései viszonylag jól követi a csapadék és a hőmérséklet országos megoszlást is. A régiók területfoglalását az 1. táblázat tartalmazza.

1. táblázat: A magyarországi régiók elnevezése (rövidítés) és területfoglalása.

\begin{tabular}{|c|c|c|}
\hline Régió elnevezése & Régió rövidítése & Terület $\left[\mathrm{km}^{2}\right]$ \\
\hline Dunántúl & $\mathrm{D}$ & 14443 \\
\hline Közép-Dunántúl & KD & 11526 \\
\hline Közép-Magyarország & $\mathrm{BK}$ & 7092 \\
\hline Észak-Alföld & EA & 18116 \\
\hline Dél-Alföld & DA & 18565 \\
\hline Nyugat-Dunántúl & NYD & 11382 \\
\hline Észak-Magyarország & EM & 13686 \\
\hline
\end{tabular}

A paraméterekre a klimatikus vizsgálatokban is szokásos 30-éves átlagokban történnek a számítások. A későbbiekben jelennek hivatkozott időszak az 1981-2010-es periódus értékeire vonatkozik. A múlt alatt az 1951-80-as időszakra utalunk. A Jövő esetében a rendelkezésre álló regionális klímamodellek adatai közül a Közép-Európára leginkább megfelelő REMO (Jacob et al., 2007) regionális klímamodell bias korrekcióval módosított adatait használtuk fel. A jövőbeli értékelési időszak a 2016-2045 közötti periódus, mivel a felhasznált adatbázisban csak 2016-tól álltnak rendelkezésre a jövőre vonatkozó adatok. Az értékeléshez az A1B szcenáriónak megfelelő változásokat vettük alapul. A kutatási munkához a FORESEE adatbázist használtuk fel (Dobor et al., 2013).

\subsubsection{HÖMÉRSÉKLETEK}

$\mathrm{Az}$ éves átlaghőmérséklet 11,1 Celsius fok, a legalacsonyabb átlaghőmérséklet ÉszakMagyarországon jellemző a Bükk-fennsíkon 10,14 fokos értékkel (2. táblázat). Ha az orográfia hatását nem számítjuk, akkor az ÉK-i területek a leghűvösebbek 9-9,5 Celsius fokos átlaghőmérséklettel. Átlaghőmérséklet tekintetében a legmelegebb terület a Dél-Alföld, ill. a Dunántúl déli része 11,6 és 11,53 Celsius fokkal. Az átlaghőmérséklet régiók szerinti megoszlást a 2. táblázat tartalmazza. A táblázatban az átlag az egyes régiókba eső pixelek éves átlaghőmérsékleteinek területi átlaga. A minimum és a maximum, valamint a szórás az adott régión belüli pixelek éves átlagértékeire értelmezett térbeli statisztikák. 
2. táblázat: Az éves átlaghőmérsékletek térbeli statisztikái a magyarországi régiókban (1981-2010).

\begin{tabular}{|c|c|c|c|c|}
\hline Régió & Min.[Celsius] & Max.[Celsius] & Átlag [Celsius] & Szórás \\
\hline D & 11,06 & 11,96 & 11,53 & 0,20 \\
\hline KD & 9,68 & 11,78 & 11,08 & 0,45 \\
\hline BK & 9,52 & 11,87 & 11,24 & 0,49 \\
\hline EA & 10,16 & 11,64 & 10,79 & 0,45 \\
\hline DA & 11,066 & 11,96 & 11,60 & 0,19 \\
\hline NYD & 10,37 & 11,58 & 10,97 & 0,21 \\
\hline EM & 8,34 & 11,28 & 10,14 & 0,61 \\
\hline
\end{tabular}

A 2. táblázat alapján megállapítható, hogy az orográfia hatását elhanyagolva a leghidegebb ÉK-i rész és a legmelegebb D-i rész között 3-3,5 Celsius fokos átlaghőmérséklet különbségek vannak, ami indokolhatja a régiók kialakítását, a pályaszerkezet méretezés hőmérsékleti korrekciójának szempontjából.

$\mathrm{Az}$ átlagok mellett a hőmérséklet szezonális menete is lényeges kérdés, hiszen a pályaszerkezet méretezés a havi jellemzők figyelembevételén alapul. A hőmérsékletek havi eloszlását a 3. táblázat mutatja.

3. táblázat: A napi átlaghőmérsékletek szezonális megoszlása (1981-2010).

\begin{tabular}{|c|c|c|c|c|c|c|}
\hline Hónap & $\begin{array}{c}\text { Min. } \\
\text { [Celsius] }\end{array}$ & $\begin{array}{c}\text { Max. } \\
\text { [Celsius] }\end{array}$ & $\begin{array}{c}\text { Átlag. } \\
\text { [Celsius] }\end{array}$ & Szórás & 0 Celsius alatt & $\begin{array}{c}30 \text { Celsius } \\
\text { fölött }\end{array}$ \\
\hline Jan. & $-20,7$ & 12,6 & $-0,57$ & 4,69 & $53,75 \%$ & $0,00 \%$ \\
\hline Febr. & $-16,9$ & 15,2 & 1,45 & 4,76 & $36,32 \%$ & $0,00 \%$ \\
\hline Már. & $-12,6$ & 18,0 & 6,09 & 4,27 & $7,39 \%$ & $0,00 \%$ \\
\hline Ápr. & $-2,0$ & 21,7 & 11,68 & 3,73 & $0,04 \%$ & $0,00 \%$ \\
\hline Máj. & 4,2 & 26,1 & 16,73 & 3,44 & $0,00 \%$ & $0,00 \%$ \\
\hline Jún. & 8,3 & 29,9 & 19,63 & 3,33 & $0,00 \%$ & $0,00 \%$ \\
\hline Júl. & 10,8 & 32,5 & 21,68 & 3,03 & $0,00 \%$ & $0,19 \%$ \\
\hline Aug. & 10,1 & 30,6 & 21,26 & 3,10 & $0,00 \%$ & $0,01 \%$ \\
\hline Szept. & 5,7 & 28,2 & 16,74 & 3,22 & $0,00 \%$ & $0,00 \%$ \\
\hline Okt. & $-2,0$ & 22,9 & 11,55 & 4,14 & $0,23 \%$ & $0,00 \%$ \\
\hline Nov. & $-11,3$ & 19,6 & 5,25 & 4,27 & $10,85 \%$ & $0,00 \%$ \\
\hline Dec. & $-15,6$ & 16,8 & 0,66 & 4,35 & $42,90 \%$ & $0,00 \%$ \\
\hline
\end{tabular}

A 3. táblázat alapján megállapítható, hogy a havi átlaghőmérsékletek a -0,6 (január) és a 21,7 (július) Celsius fok között változnak. A napi átlaghőmérsékletek esetében a leghidegebb az 1981-2010 közötti időszakban -20,7 Celsius fok, míg a legmelegebb 32,5 Celsius fok volt. A legtöbb fagypont alatti átlaghőmérsékletű nap januárban volt, átlagosan 17 nap a hónapból. Fagypont alatti hőmérsékletű napok októbertöl-áprilisig, a $30{ }^{\circ} \mathrm{C}$ fölötti átlaghömérsékletủ napok pedig dominánsan júliusban voltak jellemzőek (átlagosan 0,06 nap a hónapban).

\subsubsection{CSAPADÉK}

A csapadék esetében 586 mm/év az országos átlag az 1981-2010 közötti időszakban. A legkisebb éves átlagos csapadékösszeg Közép-Magyarországon és a Dél-Alföldön jellemző 480-490 mm/év, míg a legnagyobb csapadékú a nyugat-dunántúli régió $(614 \mathrm{~mm} /$ év$)$. A csapadék területi eloszlását a 4. táblázat mutatja.

4. táblázat: Az éves átlagos csapadékösszegek [mm/év] térbeli statisztikái a magyarországi régiókban (1981-2010).

\begin{tabular}{|c|c|c|c|c|}
\hline Régió & Min. [mm] & Max. [mm] & Átlag [mm] & Szórás \\
\hline D & 512 & 713 & 586 & 47,19 \\
\hline KD & 501 & 651 & 554 & 34,09 \\
\hline BK & 487 & 649 & 523 & 36,22 \\
\hline EA & 499 & 622 & 546 & 33,56 \\
\hline DA & 490 & 570 & 521 & 16,32 \\
\hline NYD & 505 & 764 & 614 & 66,84 \\
\hline
\end{tabular}




\begin{tabular}{|l|l|l|l|l|}
\hline EM & 505 & 671 & 574 & 36.80 \\
\hline
\end{tabular}

A csapadék havi eloszlását szemlélteti a 1. ábra, amely szerint a nyár eleji csapadékmaximum jellemző hazánkra és talajnedvesség szempontjából kritikus téli-tavaszi hónapok inkább átlagos vagy az alatti csapadékkal bírnak.

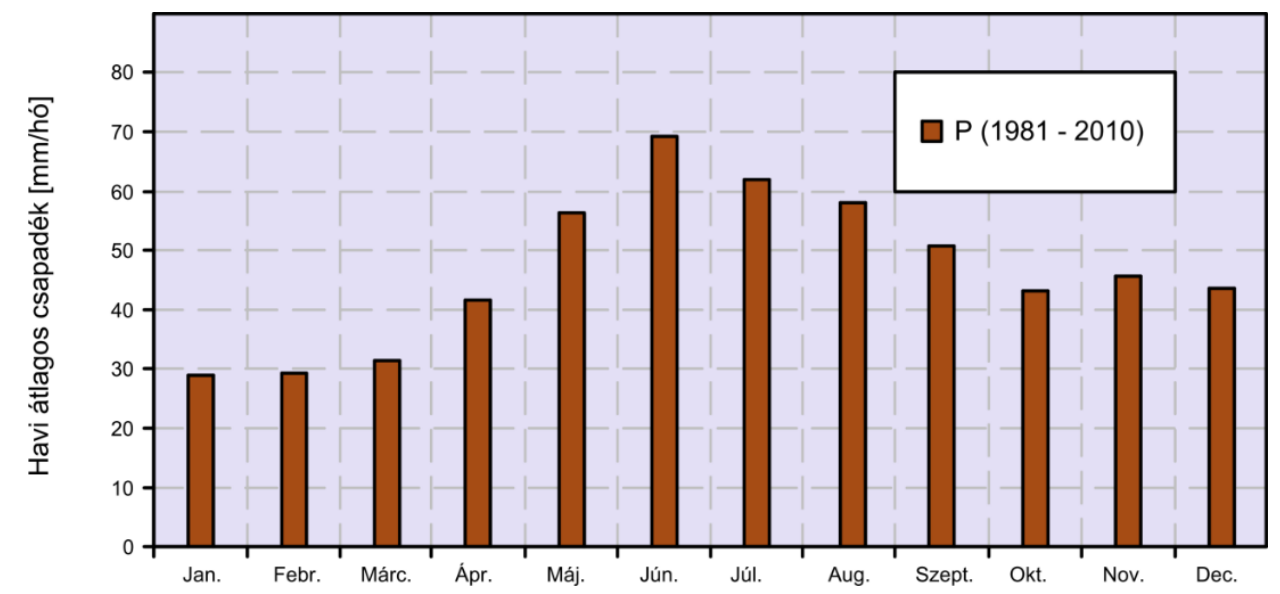

1. ábra: A havi átlagos csapadékösszegek [mm/hó] szezonális eloszlása az 1981-2010-es időszakban.

A földmü modulusaira tekintettel a tavaszi modulusok lehetnek jelentősen kisebbek alapvetően az olvadás következtében elöálló felázottság miatt (Fi et al., 2012). A felázottság a magasabb talajnedvesség értékekben jelentkezik, amire leginkább a nyugalmi időszak (november-április) csapadékösszege van hatással, ezek a csapadékok akkumulálódnak a talajban, növelve annak nedvességtartalmát. A vegetációs időszak csapadékait azért nem érdemes figyelembe venni ebből a szempontból, mert a nyári időszakban a potenciális párolgás általában magasabb, mint a csapadék, így a talajnedvesség készlet csökkenő tendenciát mutat. Az alacsonyabb talajnedvesség pedig (a szélsőségesen száraz, aszályos viszonyoktól eltekintve) egy kedvezőbb földmű modulusban nyilvánul meg. A nyugalmi időszak (téli félév) csapadékok területi eloszlást mutatja az 5. táblázat, amely szerint a hegyvidéki részeken kívül a Nagyalföld ÉK-i része, valamint a Dunántúl DNy-i területei rendelkeznek magasabb téli csapadékösszeggel.

A téli félév csapadékösszege átlagosan 146 és $231 \mathrm{~mm}$ között van, $178 \mathrm{~mm}$-es átlag értékkel. Mivel a nyugalmi időszak párolgása durván $80-100 \mathrm{~mm}$ körüli (Kovács, 2011), ezért a lefolyást is figyelembe véve (a csapadék kb. 10\%-a, ami durván $20 \mathrm{~mm}$ ) átlagosan 20 és $130 \mathrm{~mm}$ közötti csapadék áll rendelkezésre a talaj nedvességkészletének feltöltésére. A $100 \mathrm{~mm}$ fölötti csapadékmennyiség így, a kedvezőtlen agyagos talajú területeken, általában elegendő arra, hogy a gravitációs pórusméret alatti hézagokat telítse, a felső $1 \mathrm{~m}$-es talajrétegben, a szántóföldi vízkapacitásig. Az előbbi megállapítás még akkor is igaz, ha előzőleg a vegetációs időszakban a párolgás a hervadásponti víztartalomig leürítette a talaj nedvességkészletét (ami csak a szélsőségesen száraz években igaz). Számszerüen az egyes régiókra a következő átlagos téli csapadékösszegek a jellemzőek (5. táblázat). 
5. táblázat: Az átlagos téli csapadékösszegek [mm] térbeli statisztikái a magyarországi régiókban (1981-2010).

\begin{tabular}{|c|c|c|c|c|}
\hline Régió & Min.[mm] & Max. [mm] & Átlag [mm] & Szórás \\
\hline BK & 158 & 221 & 174 & 15,09 \\
\hline D & 171 & 230 & 190 & 13,94 \\
\hline DA & 160 & 192 & 174 & 6,41 \\
\hline EM & 146 & 217 & 168 & 14,90 \\
\hline NYD & 162 & 231 & 185 & 17,40 \\
\hline KD & 168 & 210 & 182 & 8,98 \\
\hline EA & 150 & 207 & 175 & 14,07 \\
\hline
\end{tabular}

\subsection{A KLIMATIKUS JELLEMZÖK MÚLTBELI (1951-1980) ALAKULÁSA MAGYARORSZÁG TERÜLETÉN}

A múltra vonatkozóan, hogy a változási tendenciákat megláthassuk érdemes a hőmérséklet és csapadékadatokat, valamint egyes levezetett jellemzőket egy korábbi azonos hosszúságú időszak méréseinek statisztikai adataival összevetni. Ez az időszak az 1951-1980 közötti periódus.

\subsubsection{HÖMÉRSÉKLET}

$\mathrm{Az}$ éves átlaghőmérséklet 10,3 Celsius fok, ami 0,7-0,8 fokkal alacsonyabb, mint a jelenre vonatkoztatott érték (1981-2010: 11,1 Celsius fok), a legalacsonyabb átlaghőmérséklet ÉszakMagyarországon jellemző a Bükk-fennsíkon 7,8 (1981-2010: 8,3 Celsius fok) Celsius fokos értékkel. Ha az orográfia hatását nem számítjuk, akkor az ÉK-i területek a leghüvösebbek 8,5-9,0 Celsius fokos (1981-2010: 9,0-9,5 Celsius fok) átlaghőmérséklettel. Átlaghőmérséklet tekintetében a legmelegebb terület a Dél-Alföld, ill. a Duna-Tisza köze keleti része, ahol 11 Celsius fokot kissé meghaladó (19812010: 12 Celsius fok) átlaghőmérsékletek jellemzőek. Az átlaghőmérséklet régiók szerinti megoszlást a 6. táblázat tartalmazza:

6. táblázat: Az éves átlaghőmérsékletek térbeli statisztikái a magyarországi régiókban (1951-1980).

\begin{tabular}{|c|c|c|c|c|}
\hline Régió & Min.[Celsius] & Max.[Celsius] & Átlag [Celsius] & Szórás \\
\hline D & 10,04 & 11,05 & 10,49 & 0,26 \\
\hline KD & 8,81 & 11,15 & 10,56 & 0,49 \\
\hline BK & 10,56 & 11,13 & 10,88 & 0,11 \\
\hline EA & 7,81 & 10,67 & 9,62 & 0,60 \\
\hline DA & 9,30 & 10,36 & 9,89 & 0,20 \\
\hline NYD & 8,64 & 10,97 & 10,11 & 0,49 \\
\hline EM & 9,76 & 10,89 & 10,33 & 0,32 \\
\hline
\end{tabular}

A 6. táblázat alapján megállapítható, hogy az orográfia hatását elhanyagolva a múltban is a leghidegebb ÉK-i rész és a legmelegebb D-i rész között 2-2,5 ${ }^{\circ} \mathrm{C}$ átlaghőmérséklet különbségek voltak (1981-2010: 3-3,5 ${ }^{\circ} \mathrm{C}$ ), ami a múltban még kevésbé indokolta volna a régiók kialakítását, a pályaszerkezet méretezés hőmérsékleti korrekciójának szempontjából.

A hőmérsékletek havi eloszlását a 7. táblázat mutatja az 1951-80-as időszakban. 
7. táblázat: A napi átlaghőmérsékletek szezonális megoszlása az 1951-80-as időszakban.

\begin{tabular}{|c|c|c|c|c|c|c|}
\hline Hónap & Min.[Celsius] & Max.[Celsius] & $\begin{array}{c}\text { Átlag } \\
\text { [Celsius] }\end{array}$ & Szórás & $\begin{array}{c}\text { 0 Celsius } \\
\text { alatt }\end{array}$ & $\begin{array}{c}30 \text { Celsius } \\
\text { fölött }\end{array}$ \\
\hline Jan. & $-21,9$ & 11,6 & $-1,88$ & 4,63 & $60,45 \%$ & $0,00 \%$ \\
\hline Febr. & $-16,4$ & 15,6 & 0,88 & 4,58 & $38,38 \%$ & $0,00 \%$ \\
\hline Már. & $-13,3$ & 17,5 & 5,24 & 4,55 & $12,84 \%$ & $0,00 \%$ \\
\hline Ápr. & $-0,3$ & 22,3 & 10,75 & 3,69 & $0,00 \%$ & $0,00 \%$ \\
\hline Máj. & 2,6 & 26,2 & 15,45 & 3,55 & $0,00 \%$ & $0,00 \%$ \\
\hline Jún. & 6,3 & 28,8 & 19,07 & 3,15 & $0,00 \%$ & $0,00 \%$ \\
\hline Júl. & 9,8 & 29,7 & 20,49 & 2,87 & $0,00 \%$ & $0,00 \%$ \\
\hline Aug. & 10,1 & 30,8 & 19,98 & 2,94 & $0,00 \%$ & $0,03 \%$ \\
\hline Szept. & 3,6 & 26,5 & 16,23 & 3,47 & $0,00 \%$ & $0,00 \%$ \\
\hline Okt. & $-1,2$ & 22,3 & 10,85 & 3,76 & $0,02 \%$ & $0,00 \%$ \\
\hline Nov. & $-8,7$ & 17,8 & 5,39 & 4,13 & $9,73 \%$ & $0,00 \%$ \\
\hline Dec. & $-16,2$ & 11,8 & 0,58 & 4,01 & $42,51 \%$ & $0,00 \%$ \\
\hline
\end{tabular}

A 7. táblázat alapján megállapítható, hogy a havi átlaghőmérsékletek a következő értékek között változnak: -1,9 Celsius fok a januári (-0,6 a január az 1981-2010) és 20,5 Celsius fok a júliusi (21,7 Celsius fok a július az 1981-2010). A napi átlaghőmérsékletek esetében a leghidegebb az 1951-80 közötti időszakban -21,9 Celsius fok (az 1981-2010 közötti időszakban -20,7 Celsius fok), míg a legmelegebb 30,8 Celsius fok volt (az 1981-2010 közötti időszakban 32,5 Celsius fok). A legtöbb fagypont alatti átlaghőmérsékletü nap 1951-80 között januárban volt, átlagos 18,7 nap a hónapból (19812010 átlagosan 17 nap a hónapból). Fagypont alatti hőmérsékletü napok, 1951-80 között is, októbertöláprilisig voltak jellemzőek. A 30 Celsius fok fölötti átlaghőmérsékletủ napok az 1951-80 közötti időszakban csak augusztusban fordultak elő minimális mértékben átlagosan 0,01 nap a hónapban (19812010 átlagosan 0,06 nap július hónapban), más nyári hónapban egyáltalán nem fordultak elö. Az összehasonlítás alapján kiderül, hogy a két harminc éves periódus között a napi átlaghőmérsékletek minimumai 1,5 Celsius fokkal emelkedtek, míg a maximális napi átlaghőmérsékletek 1,2 Celsius fokkal magasabbak. Ezek szerint a szélsőségek változásának mértéke jelentősebb, mint az átlagokban jelentkező 0,7-0,8 Celsius fokos növekedés. A fagypont alatti átlaghőmérsékletű napok 1,7 nappal csökkentek januárban, míg a 30 Celsius fok fölötti napok nőttek, 0,05 nappal több jelentkezett júliusban 1981-2010 között, mint 1951-80 között. A pályaszerkezetek vonatkozásában a fagy jelentőségének csökkenése mellett a magas hőmérsékletek (hőségnapok számának) emelkedése várható, ami a keréknyomképződés fokozódásához vezethet.

\subsubsection{CSAPADÉK}

Az éves átlagos csapadék eloszlását a 8. táblázat mutatja. A csapadék esetében $609 \mathrm{~mm} / \mathrm{e} v$ az átlagos évi csapadékösszeg az 1951-80 közötti időszakban (586 mm/év az országos átlag 1981-2010 között). A legkisebb éves átlagos csapadékösszeg 1951-80-as idöszakban Közép-Magyarországon és a DélAlföldön jellemző 560-580 mm/év (jellemző 480-490 mm 1981-2010 között), míg a legnagyobb csapadékú a nyugat-dunántúli régió 650 mm/év körüli értékkel (1981-2010: 614 mm/év).

8. táblázat: Az éves átlagos csapadékösszegek (mm/év) térbeli statisztikái a magyarországi régiókban (1951-80).

\begin{tabular}{|c|c|c|c|c|}
\hline Régió & Min.[mm/év] & Max.[mm/év] & Átlag [mm/év] & Szórás \\
\hline D & 561 & 752 & 651 & 46,72 \\
\hline KD & 551 & 693 & 604 & 29,16 \\
\hline BK & 540 & 706 & 580 & 39,13 \\
\hline EA & 547 & 659 & 594 & 31,96 \\
\hline DA & 524 & 619 & 559 & 14,67 \\
\hline NYD & 554 & 794 & 652 & 65,17 \\
\hline EM & 565 & 742 & 639 & 37,56 \\
\hline
\end{tabular}

A csapadék havi eloszlását szemlélteti a 2. ábra, amely szerint az 1951-80-as periódushoz képest az 1981-2010-es időszakban nagyobb mértékü nyár eleji és abszolút értékben véve kisebb mértékü téli 
csapadékcsökkenés volt jellemző. A kora őszi csapadékok megnőttek az ősz közepe és a tavasz eleje közel azonos csapadékú. A pályaszerkezetek szempontjából a fagy és olvadási károk téli időszakában a klíma kissé szárazabbá vált, de a mértékadó kora tavaszi időszakban alig történt változás.

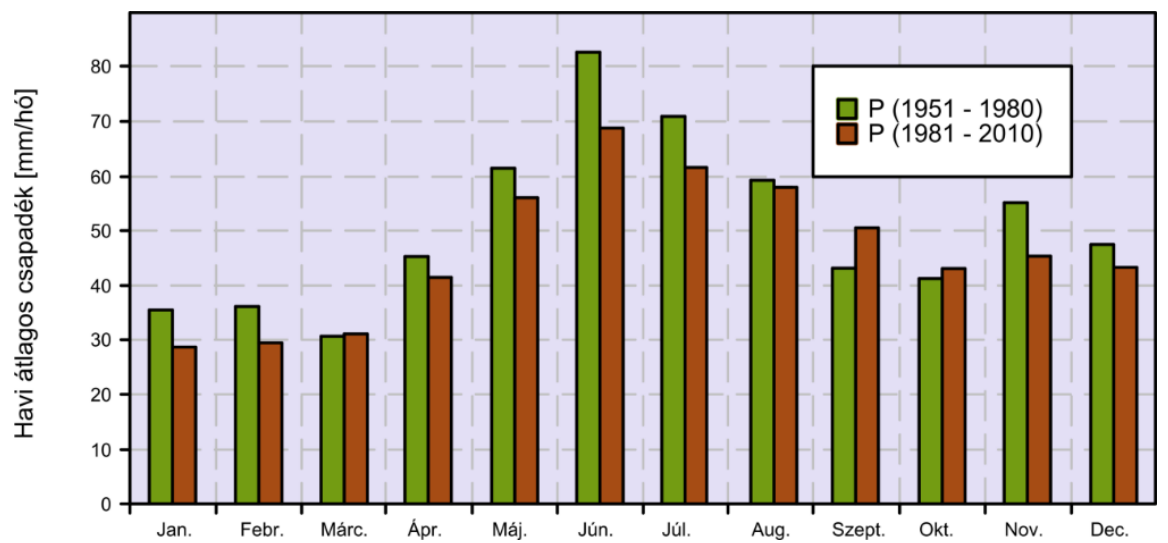

2. ábra: A havi átlagos csapadékösszegek [mm/hó] szezonális eloszlása az 1951-80, valamint az 1981-2010-es időszakban.

A nyugalmi időszak (november-április) csapadékösszegei akkumulálódva növelik jelentősen a kritikus tavaszi időszakban a földmü nedvességtartalmát.

A téli félév csapadékösszege átlagosan $181 \mathrm{~mm}$ (1981-2010: $146 \mathrm{~mm})$ és $257 \mathrm{~mm}$ (1981-2010: 231 mm) között van, 205 mm-es (1981-2010: 178mm) átlag értékkel az országban. Az átlagos tendencia tehát $27 \mathrm{~mm}$ átlagos csökkenés 30 év alatt, de a szárazabb területeken a csökkenés erősebb, míg a nedvesebb területek csökkenése kevésbé jellemző (9. táblázat).

Itt is megjegyezzük, hogy a téli párolgást és a lefolyást figyelembe véve alapvetően a $100 \mathrm{~mm}$ fölötti csapadékmennyiségek lehetnek kedvezőtlenek az alapvetően kötött talajú területeken.

9. táblázat: Az átlagos téli csapadékösszegek [mm] térbeli statisztikái a magyarországi régiókban (1951 1980).

\begin{tabular}{|c|c|c|c|c|}
\hline Régió & Min.[mm] & Max.[mm] & Átlag [mm] & Szórás \\
\hline BK & 187 & 250 & 203 & 15,74 \\
\hline D & 197 & 255 & 220 & 14,48 \\
\hline DA & 181 & 220 & 196 & 5,70 \\
\hline EA & 187 & 230 & 203 & 12,85 \\
\hline EM & 187 & 246 & 206 & 12,76 \\
\hline KD & 190 & 238 & 206 & 9,04 \\
\hline NYD & 183 & 257 & 206 & 19,45 \\
\hline
\end{tabular}

\subsection{A KLIMATIKUS JELLEMZÖK JÖVÖBELI (2016-2045) ALAKULÁSA MAGYARORSZÁG TERÜLETÉN}

A jövőben lehetséges változási tendenciák értékelésére egy a jövőre vonatkozó, klimatikus szempontból már mértékadó és azonos hosszúságú időszakot, a 2016-2045 közötti periódus lett felhasználva és összevetve a jelen (1981-2010) méréseinek statisztikai adataival.

A regionális klímamodellek közül a Közép-Európára leginkább megfelelő REMO (Jacob et al., 2007) regionális klímamodell bias korrigált adatai lettek felhasználva. A bias korrekció az 1981-2010 közötti időszak mért adatai (FORESEE adatbázis) és a REMO regionális klímamodell ugyanerre az időszakra vonatkozó futtatásai alapján készült.

\subsubsection{HÖMÉRSÉKLET}

Az évi középhőmérséklet eloszlását hazánkban a 2016-2045 közötti időszakban a 10. táblázat mutatja. $\mathrm{Az}$ éves átlaghőmérséklet 12,0 Celsius fok, ami 0,9 Celsius fokkal magasabb, mint a jelenre vonatkoztatott érték (1981-2010: 11,1 Celsius fok), a legalacsonyabb átlaghőmérséklet Észak- 
Magyarországon jellemző a jövőben is a Bükk-fennsíkon 9,3 (1981-2010: 8,3 Celsius fok) Celsius fokos értékkel. Ha az orográfia hatását nem számítjuk, akkor az ÉK-i területek, valamint az Alpokalja a leghűvösebbek 11,0-11,5 Celsius fokos (1981-2010: 9,0-9,5 Celsius fok) átlaghömérséklettel. A legmelegebb terület a Dél-Alföld, ill. a Duna-Tisza köze nyugati része, valamint a Dél-Dunántúl déli és keleti része, ahol 12,5-13 Celsius fokos (1981-2010: 12 Celsius fok) átlaghőmérsékletek jellemzőek. Az átlaghőmérséklet régiók szerinti megoszlást a 10. táblázat tartalmazza.

10. táblázat: Az éves átlaghőmérsékletek térbeli statisztikái a magyarországi régiókban (2016-2045).

\begin{tabular}{|c|c|c|c|c|}
\hline Régió & Min.[Celsius] & Max.[Celsius] & Átlag [Celsius] & Szórás \\
\hline BK & 10,41 & 12,81 & 12,18 & 0,50 \\
\hline D & 11,98 & 12,93 & 12,46 & 0,22 \\
\hline DA & 12,01 & 12,89 & 12,54 & 0,19 \\
\hline EA & 11,17 & 12,59 & 11,76 & 0,43 \\
\hline EM & 9,32 & 12,25 & 11,12 & 0,61 \\
\hline KD & 10,53 & 12,71 & 11,96 & 0,47 \\
\hline NYD & 11,16 & 12,47 & 11,79 & 0,23 \\
\hline
\end{tabular}

A 10. táblázat alapján megállapítható, hogy a REMO regionális klímamodell prognózisa alapján, az orográfia hatását elhanyagolva, a jövőben a leghidegebb ÉK-i rész és a legmelegebb D-i rész között 3,5 Celsius fokos átlaghőmérséklet különbségek valószínűsíthetők (1981-2010: 3-3,5 Celsius fok). Ez a területi különbség a jelenhez közel hasonló mértékben teheti indokolttá régiók alkalmazását a pályaszerkezet méretezés hőmérsékleti korrekciójának szempontjából.

A hőmérsékletek havi eloszlását a 11. táblázat mutatja az 2016-2045-ös időszakban.

11. táblázat: A napi átlaghőmérsékletek szezonális megoszlása az 2016-2045-ös időszakban.

\begin{tabular}{|c|c|c|c|c|c|c|}
\hline Hónap & Min.[Celsius] & Max.[Celsius] & $\begin{array}{c}\text { Átlag } \\
\text { [Celsius] }\end{array}$ & Szórás & $\begin{array}{c}\mathbf{0} \text { Celsius } \\
\text { alatt }\end{array}$ & $\begin{array}{c}\mathbf{3 0} \\
\text { Celsius } \\
\text { fölött }\end{array}$ \\
\hline Jan. & $-16,00$ & 11,90 & $-0,05$ & 4,40 & $50,76 \%$ & $0,00 \%$ \\
\hline Febr. & $-16,70$ & 15,50 & 2,81 & 4,85 & $24,53 \%$ & $0,00 \%$ \\
\hline Már. & $-6,80$ & 20,50 & 6,64 & 3,97 & $5,93 \%$ & $0,00 \%$ \\
\hline Ápr. & $-2,10$ & 24,30 & 12,26 & 3,46 & $-0,10 \%$ & $0,00 \%$ \\
\hline Máj. & 3,90 & 26,60 & 17,45 & 3,78 & $0,00 \%$ & $0,00 \%$ \\
\hline Jún. & 9,50 & 31,40 & 20,48 & 3,49 & $0,00 \%$ & $0,76 \%$ \\
\hline Júl. & 8,70 & 35,20 & 22,77 & 3,27 & $0,00 \%$ & $3,07 \%$ \\
\hline Aug. & 12,00 & 32,30 & 22,56 & 3,07 & $0,00 \%$ & $2,14 \%$ \\
\hline Szept. & 7,50 & 32,00 & 18,06 & 3,20 & $0,00 \%$ & $0,34 \%$ \\
\hline Okt. & $-0,20$ & 22,90 & 13,01 & 4,26 & $0,22 \%$ & $0,00 \%$ \\
\hline Nov. & $-2,80$ & 17,40 & 5,87 & 3,88 & $8,20 \%$ & $0,00 \%$ \\
\hline Dec. & $-14,90$ & 16,50 & 1,44 & 4,07 & $36,67 \%$ & $0,00 \%$ \\
\hline
\end{tabular}

A 11. táblázat alapján megállapítható, hogy a havi átlaghőmérsékletek a -0,1 Celsius fok a januári (0,6 a január az 1981-2010) és 22,8 Celsius fok a júliusi (21,7 Celsius fok a július az 1981-2010) között változnak. A napi átlaghőmérsékletek esetében a leghidegebb a 2016-2045 közötti időszakban -16,7 Celsius fok (az 1981-2010 közötti időszakban -20,7 Celsius fok), míg a legmelegebb 35,2 Celsius fok (az 1981-2010 közötti időszakban 32,5 Celsius fok) mint jövőben várható értékek. Az összehasonlítás alapján kiderül, hogy a két harminc éves periódus között a napi átlaghőmérsékletek minimumai emelkednek, míg a maximális napi átlaghőmérsékletek jelentősen (több fokkal) magasabbak is lehetnek. Ezek szerint a szélsőségek változásának mértéke a meleg nyári hónapokban jelentősebb lesz, mint az átlagokban jelentkező növekedés. A fagypont alatti átlaghőmérsékletü napok csökkennek a téli időszakban (mintegy 6-7 nappal évente). Míg a 30 Celsius fok fölötti napok száma is nő és már nemcsak júliusban és augusztusban, hanem májustól szeptemberig előfordulhatnak majd. A pályaszerkezetek vonatkozásában a fagyos napok jelentősége csökken, ami az olvadási károkkal sújtott időszak hosszának 
növekedését jelentheti. Míg a magas hőmérsékletek (hőségnapok számának) emelkedése várható, ami a keréknyomképződés fokozódásához vezethet.

\subsubsection{CSAPADÉK}

Az éves átlagos csapadék eloszlását a 12. táblázat mutatja. A csapadék esetében $527 \mathrm{~mm} / \mathrm{é}$ az átlagos évi csapadékösszeg a 2016-2045 közötti időszakban (586 mm/év az országos átlag az 1981-2010). A legkisebb éves átlagos csapadékösszeg 1951-80-as időszakban a Kiskunság Északi részén jellemző 400$450 \mathrm{~mm}$ (de az egész Nagyalföld középső részen $500 \mathrm{~mm} /$ év alatt marad az éves csapadék), míg a legnagyobb csapadékú a délnyugat-dunántúli régió 604 mm/év körüli értékkel (1981-2010 614 mm/év).

12. táblázat: Az éves átlagos csapadékösszegek [mm/év] térbeli statisztikái a magyarországi régiókban (2016-2045).

\begin{tabular}{|c|c|c|c|c|}
\hline Régió & Min.[mm/év] & Max.[mm/év] & Átlag [mm/év] & Szórás \\
\hline BK & 442 & 629 & 482 & 44,04 \\
\hline D & 456 & 691 & 554 & 54,27 \\
\hline DA & 443 & 545 & 489 & 25,13 \\
\hline EA & 452 & 585 & 505 & 33,24 \\
\hline EM & 461 & 646 & 543 & 41,72 \\
\hline KD & 458 & 621 & 521 & 38,89 \\
\hline NYD & 497 & 731 & 604 & 55,85 \\
\hline
\end{tabular}

A Boromissza-féle méretezési praktikum (Boromissza, 1997) térképével összehasonlítva megállapítható, hogy a 600 mm/éves izohiéta közel azonos helyen áll, mint az 1981-2010-es időszakban. Az 1981-2010 közötti időszakkal összehasonlítva az Alföld középső része és a Keleti országrész szárazodó tendenciát mutat.

A csapadék havi eloszlását szemlélteti a 3. ábra, amely szerint az 1981-2010-es periódushoz képest az 2016-2045-ös időszakban a téli csapadékösszeg közel változatlan volta mellett (kisebb növekedés decemberben) a nyári csapadékösszeg jelentősebb csökkenése várható. A pályaszerkezetek szempontjából a fagy és olvadási károk téli időszakában a csapadékosság hasonló marad. Az elemzéshez azonban érdemes hozzáfüzni, hogy a klímamodellek csapadékeloszlása jelentősen eltérhet a valós csapadékeloszlástól, így ezeket az eredményeket fenntartással érdemes kezelni.

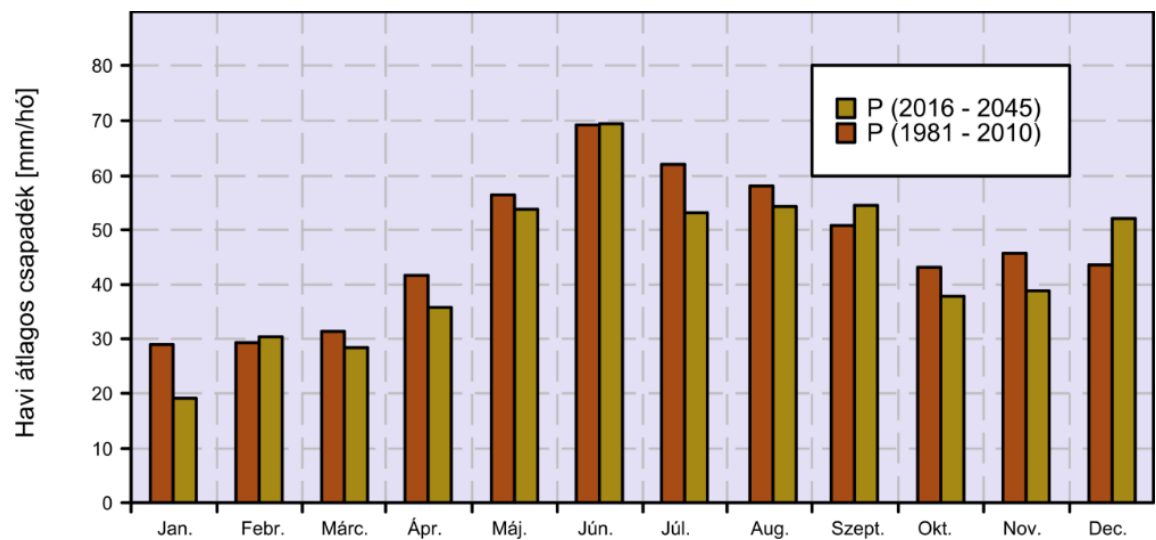

3. ábra: A havi átlagos csapadékösszegek [mm/hó] szezonális eloszlása a 2016-2045, valamint az 1981-2010-es időszakban.

A jelenhez hasonlóan a lehetséges jövőre vonatkozóan elemezzük a nyugalmi időszak (novemberáprilis) csapadékösszegeit, hiszen ezek a csapadékok akkumulálódva növelhetik majd a kritikus tavaszi időszakban a földmủ nedvességtartalmát.

A téli félév csapadékösszege átlagosan $131 \mathrm{~mm}$ (1981-2010 $146 \mathrm{~mm})$ és $254 \mathrm{~mm}$ (1981-2010 231 mm) között van,171 mm-es (1981-2010 $178 \mathrm{~mm}$ ) átlagos értékkel az országban. Az átlagos tendencia tehát alig $7 \mathrm{~mm}$ átlagos csökkenés a térbeli szélsőségek növekedése mellett (13. táblázat). Az előbbiek szerint a téli félév csapadékösszege mintegy $15 \mathrm{~mm}$-es csökkenéssel jellemezhető majd. A tavasz 
csapadékcsökkenése ennél jelentősebb lesz, a melegedés pedig valószínüleg többletpárolgással jár majd. Ezek a hatások valószínüleg csökkentik majd a tavaszi talajnedvességeket.

Itt is megjegyezzük, hogy a téli párolgást és a lefolyást figyelembe a $100 \mathrm{~mm}$ fölötti téli csapadékösszegek lehetnek kedvezötlenek az alapvetően kötött talajú területeken.

13. táblázat: Az átlagos téli csapadékösszegek [mm] térbeli statisztikái a magyarországi régiókban (2016 2045).

\begin{tabular}{|c|c|c|c|c|c|}
\hline Régió & Pixel & Min. [mm] & Max. [mm] & Átlag [mm] & Szórás [mm] \\
\hline BK & 7079 & 137.852 & 207.871 & 155.64 & 17,91 \\
\hline D & 14429 & 148.293 & 246.401 & 186.48 & 22,80 \\
\hline DA & 18545 & 138.541 & 191.915 & 162.07 & 11,08 \\
\hline EA & 18041 & 132.370 & 214.544 & 162.56 & 18,52 \\
\hline EM & 13438 & 130.870 & 205.357 & 155.98 & 16,60 \\
\hline KD & 11454 & 148.216 & 208.271 & 177.65 & 14,93 \\
\hline NYD & 11177 & 172.161 & 254.821 & 204.78 & 19,06 \\
\hline
\end{tabular}

\section{5. ÖSSZEFOgLALÁs}

A cikkben, a klimatikus jellemzők hatásai az útpályaszerkezetre a három vizsgálati periódusban (1951-1980; 1981-2010; 2016-2045) a következőképpen foglalhatók össze:

A jövőre (2016-2045) vonatkoztatott éves átlaghőmérséklet $12,0{ }^{\circ} \mathrm{C}$, ami 0,9 Celsius fokkal magasabb, mint a jelenre (1981-2010: $\left.11,1^{\circ} \mathrm{C}\right)$, és 1,7 fokkal magasabb, mint a múltban (19511980: $10,3^{\circ} \mathrm{C}$ ) kapott értékek.

Ha az orográfia hatását nem számítjuk, akkor az ÉK-i területek, valamint az Alpokalja a leghüvösebbek 11,0-11,5 Celsius fokos átlaghőmérséklettel (1981-2010: 9,0-9,5 ${ }^{\circ} \mathrm{C}$; 1951 1980: 8,5-9,0 ${ }^{\circ} \mathrm{C}$ ). A legmelegebb terület a Dél-Alföld, ill. a Duna-Tisza köze nyugati része, valamint a Dél-Dunántúl déli és keleti része, ahol $12,5-13{ }^{\circ} \mathrm{C}$ átlaghömérsékletekkel számolhatunk (1981-2010: $12{ }^{\circ} \mathrm{C}$; 1951-1980: 11 Celsius fokot kissé meghaladó). A jövőben a leghidegebb ÉK-i rész és a legmelegebb D-i rész között 3,5 ${ }^{\circ} \mathrm{C}$ átlaghőmérséklet különbségek valószínüsíthetők (1981-2010: 3-3,5 ${ }^{\circ} \mathrm{C}$; 1951-1980: 2-2,5 $\left.{ }^{\circ} \mathrm{C}\right) . \mathrm{Ez}$ a területi különbség a jelenhez közel hasonló mértékben teheti indokolttá régiók alkalmazását a pályaszerkezet méretezés hőmérsékleti korrekciójának szempontjából.

Az 1981-2010 és a 2016-2045 periódus között a napi átlaghőmérsékletek minimumai emelkednek, míg a maximális napi átlaghőmérsékletek jelentősen (több fokkal) magasabbak is lehetnek. Ezek szerint a szélsőségek változásának mértéke a meleg nyári hónapokban jelentősebb lesz, mint az átlagokban jelentkező növekedés. Az 1951-1980 és a 1981-2010 periódusok között a napi átlaghőmérsékletek minimumai $1,5^{\circ} \mathrm{C}$-kkal emelkedtek, míg a maximális napi átlaghőmérsékletek $1,2^{\circ} \mathrm{C}$-kkal magasabbak. A szélsőségek változásának mértéke tehát jelentősebb, mint az átlagokban jelentkező 0,7-0,8 Celsius fokos növekedés.

Az 2016-2045-ös periódusban fagypont alatti átlaghőmérsékletü napok csökkennek, mintegy 6-7 nappal évente az 1981-2010-es, és 7,7-8,7 nappal a 1951-1980-as periódushoz képest. Míg a $30{ }^{\circ} \mathrm{C}$ fölötti napok száma nő a jövőben. A pályaszerkezetek vonatkozásában a fagyos napok jelentősége tehát csökken, ami az olvadási károkkal sújtott időszak hosszának növekedését jelentheti, a hőségnapok számának emelkedése pedig a keréknyomképződés fokozódásához vezethet.

A csapadék esetében $527 \mathrm{~mm} /$ év az átlagos évi csapadékösszeg a 2016-2045 közötti időszakban (1981-2010: 586 mm/év; 1951-1980: 609 mm/év).

A legkisebb éves átlagos csapadékösszeg 2016-2045-ben a Nagyalföld középső részén várható (<500 mm/év). Az 1951-80-as időszakban Közép-Magyarországon és a Dél-Alföldön 580 mm/év, míg 520 mm/év 1981-2010 között. A legnagyobb csapadékú a délnyugat- dunántúli régió $604 \mathrm{~mm} / \mathrm{év}$ értékkel (1981-2010: 614 mm/év; 1951-1980: $650 \mathrm{~mm} / \mathrm{v}$ ).

A csapadék havi eloszlása szerint az 1981-2010-es periódushoz képest a 2016-2045-ös időszakban a téli csapadékösszeg közel változatlan volta mellett a nyári csapadékösszeg jelentősebb csökkenése 
várható. A csapadék havi eloszlása szerint az 1951-80-as periódushoz képest az 1981-2010-es időszakban nagyobb mértékü nyár eleji és abszolút értékben véve kisebb mértékü téli csapadékcsökkenés volt jellemzö. A kora őszi csapadékok megnőtek az ősz közepe és a tavasz eleje közel azonos csapadékú.

A pályaszerkezetek szempontjából a fagy és olvadási károk téli időszakában a csapadékosság hasonló marad mindhárom vizsgálati periódusban. Az elemzéshez hozzáfüzendő, hogy a klímamodellek csapadékeloszlása jelentősen eltérhet a valóstól, így ezeket az eredményeket fenntartással érdemes kezelni. A nyugalmi időszak (november-április) csapadékösszegei akkumulálódva növelik jelentősen a kritikus tavaszi időszakban a földmü nedvességtartalmát.

A téli félév csapadékösszege átlagosan $171 \mathrm{~mm}$ (1981-2010 $178 \mathrm{~mm} ; 1951-1980: 205 \mathrm{~mm}) \mathrm{az}$ országban. Az átlagos tendencia tehát alig $7 \mathrm{~mm}$ átlagos csökkenés a jövőben, a jelenhez, de $34 \mathrm{~mm}$-es csökkenést a múlthoz képest, a térbeli szélsőségek növekedése mellett. A tavasz csapadékcsökkenése várhatóan jelentős lesz, a melegedés pedig többletpárolgással jár majd. Ezek a hatások valószínüleg csökkentik majd a tavaszi talajnedvességeket.

A téli párolgást és a lefolyást figyelembe véve a $100 \mathrm{~mm}$ fölötti téli csapadékösszegek lehetnek kedvezötlenek az alapvetően kötött talajú területeken.

\section{KÖSZÖNETNYILVÁNÍTÁS:}

A publikáció megírását az EFOP 362-16-2017-00018 „Termeljünk együtt a természettel Az agrárerdészet, mint új kitörési lehetőség” pályázat támogatta.

\section{IRODALOMJEGYZÉK}

Bartholy, J., Bozó L. \& Haszpra L. (szerk.) 2011: Klímaváltozás - 2011. Klímaszcenáriók a Kárpátmedence térségére. Magyar Tudományos Akadémia és az Eötvös Loránd Tudományegyetem Meteorológiai Tanszéke, Budapest, p. 281.

Boromissza, T. 1997: Méretezési Praktikum, Aszfaltburkolatú útpályaszerkezetek méretezési gyakorlata, Közúti közlekedési füzetek 16, Közlekedési, Hírközlési és Vízügyi Minisztérium, Budapest, p. 82.

Boromissza, T., Detre, Gy., Lazányi, I. \& Szalai, S. 2007: Az útépítési fagyhatárzónák pontosítása. Közúti és mélyépítési szemle, 6. szám: 16-21.

Christensen, J. H. \& Christensen, O.B. 2007: A summary of the PRUDENCE model projections of changes in European climate by the end of this century, Climatic Change 81:7-30, https://doi.org/10.1007/s10584-006-9210-7

Fi, I., Boncs, P., Pethö, L. \& Tóth, Cs. 2012: Útburkolatok méretezése. Terc Kft. ISBN 9789639968 349, p. 457.

Gálos, B., Lorenz, Ph. \& Jacob, D. 2007: Will dry events occur more often in Hungary in the future? Environ. Res. Lett., 2, 034006 (9pp), https://doi.org/10.1088/1748-9326/2/3/034006

Gálos, B., Antal V., Czimber, K. \& Mátyás, Cs. 2014: Forest ecosystems, sewage works and droughts - possibilities for climate change adaptation. In: Santamarta J.C., Hernandez-Gutiérrez L.E., Arraiza M.P. (eds) 2014. NaturalHazards and Climate Change/Riesgos Naturales y Cambio Climático. Madrid: Colegio de Ingenieros de Montes. ISBN 978-84-617-1060-7, D.L. TF 565-2014, 91-104, https://doi.org/10.13140/RG.2.1.3947.6963

Gálos, B. \& Vig, P. 2014: Éghajlati tendenciák a Kárpát medencében és Zala megyében. In: Bidló A., Király A., Mátyás Cs. (szerk.) Agrárklíma: Az előrevetített klímaváltozás hatáselemzése és az alkalmazkodás lehetősége, Nyugat-Magyarországi Egyetem Kiadó, Sopron, 2014. 7-16. (ISBN:978963-334-204-6)

Gáspár, L. 2007: A klímaváltozás és az útburkolatok. Közúti és mélyépítési szemle. 2007 március, 3. szám: 1-6. 
Gupta, A. 2014: „A review of Environmental Factors on Flexible Pavement Modelling”, Modern Traffic and Transportation Engineering Research, vol:3 iss:1 pg:14-20

IPCC 2014: Climate Change 2014: Synthesis Report. Contribution of Working Groups I, II and III to the Fifth Assessment Report of the Intergovernmental Panel on Climate Change [Core Writing Team, R.K. Pachauri and L.A. Meyer (eds.)]. IPCC, Geneva, Switzerland, 151 pp.

Jacob, D., Barring, L., Christensen, Ob., Christensen, JH., Castro, M., DeUe, M., Giorgi, F., Hagemann, S., Hirschi, M., Jones, R., Kjellström, E., Lenderink, G., Rockel, B., Sanchez, E., Schar, C., Seneviratne, SI., Somot, S., Van Ulden, A. \& Van Den Hurk, B. 2007: An inter-comparison of regional climate models for Europe: model performance in present-day climate. ClimChange, 81:31-52, https://doi.org/10.1007/s10584-006-9213-4

Jacob, D., Kotova, L., Lorenz, P., Moseley, C. \& Pfeifer, S. 2008: Regional climate modeling activities in relation to the CLAVIER project. Idójárás 112: 141-153.

Jacob, D., et 38 coauthors EURO-CORDEX 2014: newhigh-resolution climate change projections for European impact research, RegEnvironChange, http://doi.org/10.1007/s10113-013-0499-2

Kovács, Á. 2011: Tó- és területi párolgás becslésének pontosítása és magyarországi alkalmazásai. $\mathrm{PhD}$ értekezés. Budapesti Müszaki és Gazdaságtudományi Egyetem.

Lakatos, M., Szépszó, G., Bihari, Z., Krüzselyi, I., Szabó, P., Bartholy, J., Pongrácz, R., Pieczka, I. \& Torma, CS. (szerk.) 2012: HREX jelentés: Éghajlati szélsőségek változásai Magyarországon: Közelmúlt és jövő. http://www.met.hu/doc/IPCC_jelentes/HREX_jelentes-2012.pdf [Climate extreme changes in Hungary: recent past and future] (in Hungarian)

van der Linden, P. \& Mitchell, J.F.B. (eds.) 2009: ENSEMBLES: ClimateChange and its Impacts: Summary of research and results from the ENSEMBLES project. 160pp, Met Office Hadley Centre, FitzRoyRoad, Exeter EX1 3PB, UK

Nováky, B. \& Bálint, G. 2013: Shifts and Modification of the Hydrological Regime Under Climate Change in Hungary; http://doi.org/10.5772/54768

Pethő, L. 2008: A hőmérséklet eloszlás alakulása az aszfalt burkolatú pályaszerkezetekben és ennek hatása a pályaszerkezeti rétegek méretezésére, technológiai tervezésére. PhD értekezés. Budapesti Müszaki és Gazdaságtudományi Egyetem.

Pongrácz, R., Bartholy, J. \& Miklós, E. 2011: Analysis of projected climate change for Hungary using ENSEMBLES simulations. Applied Ecology and Environmental Research, 9(4), 387-398, https://doi.org/10.15666/aeer/0904 387398

Szalai, S. \& Mika, J. 2007: A klímaváltozás és időjárási anomáliák előrejelzése az erdőtakaró szempontjából fontos tényezőkre. In Mátyás Cs.,Vig P. (szerk). Erdő és klima V. Sopron.

Szépszó, G. 2008: Regional change of climate extremes in Hungary based on different regional climate models of the PRUDENCE project, Időjárás 112 265-83.

Ureczky, J., \& Tóth, Cs. 2008: A hőmérséklet teherbírásra gyakorolt hatásának vizsgálata. Közúti és mélyépítési szemle., 2008 április, 3. szám. 9-14.

Vautard, R., Gobiet, A., Jacob, D. et 25 coauthors 2013: 41: 2555. https://doi.org/10.1007/s00382$\underline{013-1714-\mathrm{Z}}$

Vautard, R., Gobiet, A., Sobolowski, S., Kjellström, E., Stegehuis, A., Watkiss, P., Menglik, T., Landgren, O., Nikulin, G., Teichmann, C. \& Jacob, D. 2014: The European climate under a $2{ }^{\circ} \mathrm{C}$ global warming, Environ. Res. Lett. 9034006 (11pp), https://doi.org/10.1088/1748-9326/9/3/034006 